An ASABE Meeting Presentation

Paper Number: 071028

\title{
Spatially Monitoring Tractor Performance to Evaluate Energy Requirements of Variable Depth Tillage and Implement Selection
}

Corey M. Kichler, Auburn University, 200 Tom Corley Building, Auburn, AL 36849;

John P. Fulton, Auburn University, 200 Tom Corley Building, Auburn, AL 36849

Randy L. Raper, USDA National Soil Dynamics Laboratory, Auburn, AL 36832

Wesley C. Zech, Auburn University, 283 Harbert Engineering Center, Auburn, AL 36849

Timothy P. McDonald, Auburn University, 200 Tom Corley Building, Auburn, AL 36849

Christian J. Brodbeck, Auburn University, 200 Tom Corley Building, Auburn, AL 36849

\author{
Written for presentation at the \\ 2007 ASABE Annual International Meeting \\ Sponsored by ASABE \\ Minneapolis Convention Center \\ Minneapolis, Minnesota \\ 17 - 20 June 2007
}

\begin{abstract}
Recent rises in fuel costs have started to impact the bottom line for farm managers, making them consider possible methods to achieve energy savings. Conventional subsoiling can be performed deeper than necessary to alleviate compaction layers. However, site-specific subsoiling permits a subsoiler to be operated at the depth necessary to impale the compaction layer thus, reducing draft forces while also saving fuel. The overall goal of this study was to develop a mobile data acquisition system to monitor equipment performance parameters in real-time to assess and quantify energy requirements for site-specific tillage. A data acquisition system was developed to collect and monitor slip, fuel consumption, axle torque, and draft load data on two site-specific tillage experiments. Results indicated a $54 \%$ reduction in draft forces and a $17 \%$ reduction in fuel consumption occurred with a shallow depth (9 in.) compared to a deep depth (14 in.). The three
\end{abstract}

\footnotetext{
The authors are solely responsible for the content of this technical presentation. The technical presentation does not necessarily reflect the official position of the American Society of Agricultural and Biological Engineers (ASABE), and its printing and distribution does not constitute an endorsement of views which may be expressed. Technical presentations are not subject to the formal peer review process by ASABE editorial committees; therefore, they are not to be presented as refereed publications. Citation of this work should state that it is from an ASABE meeting paper. EXAMPLE: Author's Last Name, Initials. 2007. Title of Presentation. ASABE Paper No. 07xxxx. St. Joseph, Mich.: ASABE. For information about securing permission to reprint or reproduce a technical presentation, please contact ASABE at rutter@asabe.org or 269-429-0300 (2950 Niles Road, St. Joseph, Ml 49085-9659 USA).
} 
implement time rotation experiments produced increased fuel consumption, draft loads, and axle torque with longer time spacing. The Bigham Brothers Paratil ${ }^{\circledR}$ experienced increases of 8\%, 25\%, and $21 \%$ in fuel consumption, draft forces, and torque, respectively, with the triennial time rotation compared to the annual and biennial rotations. The Kelley Manufacturing Company (KMC) in-row subsoiler experienced increases of $6 \%, 24 \%$, and $18 \%$ in fuel consumption, draft forces, and torque, respectively, with the triennial rotation compared to the annual and biennial rotations.

Keywords. GPS, GIS, data acquisition, precision agriculture, tractor performance, spatial analysis, site-specific tillage.

The authors are solely responsible for the content of this technical presentation. The technical presentation does not necessarily reflect the official position of the American Society of Agricultural and Biological Engineers (ASABE), and its printing and distribution does not constitute an endorsement of views which may be expressed. Technical presentations are not subject to the formal peer review process by ASABE editorial committees; therefore, they are not to be presented as refereed publications. Citation of this work should state that it is from an ASABE meeting paper. EXAMPLE: Author's Last Name, Initials. 2007. Title of Presentation. ASABE Paper No. 07xxxx. St. Joseph, Mich.: ASABE. For information about securing permission to reprint or reproduce a technical presentation, please contact ASABE at rutter@asabe.org or 269-429-0300 (2950 Niles Road, St. Joseph, Ml 49085-9659 USA). 


\section{Introduction}

Tillage, especially subsoiling, is an energy intensive activity that can be costly if performed frequently and at deep depths to ameliorate soil compaction. With recent increases in fuel prices, tillage has become an even bigger expense to producers and should be considered during management decisions. Proper adjustments to equipment, operating techniques, and implement selection can increase working efficiency leading to a decrease in fuel consumption. Site-specific tillage is one modern tillage method that eliminates consuming excessive energy for unnecessary uniform-depth deep tillage (Raper et al., 2005a). Site-specific tillage is performed by executing tillage no deeper that the depth of the hardpan. Tilling at variable depths can reduce energy requirements and minimize disturbance of surface residue needed for erosion control (Raper et.al., 2005a). Raper et al. (2005a) performed a study on an 8-ha field that was split up into $25 \mathrm{~cm}, 35 \mathrm{~cm}$, and $45 \mathrm{~cm}$ tillage depth zones. A tractor implemented with a row crop ripper mounted to a three point hitch dynamometer that collected draft forces was used to perform site-specific and deep tillage operations. The $25 \mathrm{~cm}$ and $35 \mathrm{~cm}$ tillage depths created a $59 \%$ and $35 \%$ reduction in draft forces, respectively, compared to the $45 \mathrm{~cm}$ depth. Power reductions of $52 \%$ and $25 \%$ were noticed with the $25 \mathrm{~cm}$ and $35 \mathrm{~cm}$, respectively, compared to uniform depth deep tillage (Raper et al., 2005a). Fuel consumption reduction experienced included a $43 \%$ and $27 \%$ at $25 \mathrm{~cm}$ and $35 \mathrm{~cm}$ depths, respectively, compared to the $45 \mathrm{~cm}$ deep subsoiling. Fulton et al. (1996) concluded that site-specific subsoiling could have a $50 \%$ decrease in fuel consumption compared to uniform-depth tillage. AbbaspourGilandeh et al. (2005) also reported that energy and fuel usage savings of $50 \%$ and $30 \%$, respectively, could be attained using variable-depth tillage.

In conservation tillage systems, topsoil disruption is minimized, but belowground soil disruption is necessary for alleviation of the compaction layer. Raper (2002) researched straight and bentleg subsoilers and their influences on aboveground soil disruption, belowground soil disruption, and draft forces. To simulate field conditions, a compaction layer was artificially created in two different soil types: 1.) a Norfolk sandy loam and 2.) Decatur clay loam. Individual shanks of many designs were tested in the soil bins. Results indicated the bentleg design shank had lower draft forces for both soil types compared to straight shank. Raper et al. (2005b) studied the effects of tillage time rotation on draft forces and cotton yields for three different implements. Annual, biennial, and triennial time rotations of subsoiling with Kelley Manufacturing Company (KMC) in-row subsoiler, Bigham Brothers Paratill ${ }^{\circledR}$, and Bigham Brothers TerraTill ${ }^{\circledR}$ implements were used. Result for year one indicated that the KMC subsoiler

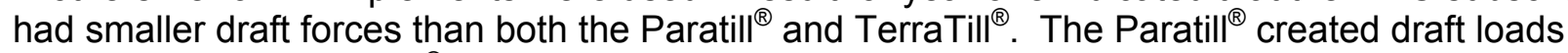
smaller than the TerraTill ${ }^{\circledR}$. The results also showed that as time between tillage events increased, the draft loads increased. The second year of the study produced different trends indicating no differences in draft forces between implements.

Shrock et al. (1982) developed a system which monitored engine speed, transmission speed, and fuel injector pump rack position to predict performance and suggest an alternative gear and throttle setting which improves the efficiency of the machine. The microprocessor's suggestions were based on the "gear up, throttle down" operating technique which suggests using a higher gear and lower throttle setting to maintain the desired travel speed to reduce fuel consumption. It was reported that this operating technique also reduced engine load for operations requiring $65 \%$ or less of the full rated power for a tractor (Grisso and Pitman, 2001). Yule et al. (1999) developed a data acquisition system to monitor and display tractor performance which also used differential global positioning system (DGPS) positions to identify areas of low operating efficiency. The in-cab display provided the operator with real-time information to help maintain optimal operating efficiency. 
The overall goal of this research is to assess the actual energy requirements of site-specific tillage to develop cost-effective management strategies for proper implementation. The objectives of this paper are to 1) develop a data acquisition system to monitor tractor performance parameters, and 2) collect and analyze tractor performance and draft data for different site-specific tillage experiments.

\section{Methods}

\section{Data Acquisition System}

The ability to collect spatial equipment performance can be a beneficial tool in making farm management decisions. A mobile data acquisition system was developed to provide information about equipment performance in real-time. System features allow the operator to view equipment performance parameters in real-time through a graphical user interface (GUI) as well as have the option to log data to a file. The major components of the system include a portable computer console, data acquisition modules, and parameter sensors. Parameters of interest are: fuel consumption, draft force, global positioning system (GPS) location, ground speed, wheel speed, and axle torque.

\section{Sensors}

Fuel consumption was measured with a fuel flow meter by Corrsys Datron Systems. This mobile unit automatically measures fuel consumption with return fuel consideration for diesel engines and outputs a pulse signal. GPS location information was provided by a Trimble Ag132 using wide area augmentation system (WAAS) correction. A Dickey-John ground speed radar was used to get vehicle travel speed. Most tractors have an integrated sensor in the transmission that provides a wheel speed signal. The travel speed and wheel speed were used to calculate slip for the operations. A Binsfeld Engineering Inc. torque telemetry system was used to measure axle torque. This system operates with a strain gauge adhered to the axle shaft and the signal is broadcasted through a transmitter to a receiver that outputs an analog signal. The analog signal is multiplied by a predetermined constant to obtain torque in $\mathrm{ft}-\mathrm{lbs}$. The 3-point hitch dynamometer is designed to measure draft force in 3 dimensions: vertical, horizontal, and side via load cells. The dynamometer is a frame design that mounts between the tractor and the implement.

\section{Signaling Modules}

Signals compatible with the data acquisition system include analog, digital, and frequency outputs. Measurement Computing ${ }^{\mathrm{TM}}$ universal serial bus (USB) modules accommodate analog, digital, and thermocouple signals. The modules are compact making the system easy to move from equipment to equipment. Frequency outputs are signals that pulse depending on the state of the transducer. These pulses are counted over a certain span of time thus obtaining a frequency. Frequency signals produced by devices such as the fuel consumption monitor, transmission sensor, and ground speed radar were processed by a custom made 6 channel counter board. The system has a total capacity of 8 analog, 16 digital, 8 thermocouple, and 7 counter signals so expansion of sensors is easily accomplished. 


\section{Program Development}

A ZYNX ${ }^{\circledR}$ X-15 computer console manufactured by KEE TM Technologies was chosen for the interface between the signal modules and the user. This is a touch screen unit which eliminates the need for a mouse in such applications. A program configured in visual basic (VB) was used to collect the signals from the various modules and convert them to usable values. National Marine Electronics Association (NMEA) data strings outputted from the GPS were received through a serial port connection and processed into a usable format in real-time with the program. The program has an integrated GUI that displays easy to use program controls along with the parameters collected from the equipment. Logging options allow you to choose a file location and a file name for which the data is to be logged. All files were collected as ".txt" files for ease of importing into Excel $^{\mathrm{TM}}$ format. Adjustments to equipment setup are easily tuned with the aid of instant feedback provided by the GUI. The system was easily removed and reinstalled on another tractor within hours proving its mobility. The draft force data was collected with a SOMAT 2100 data acquisition system separate from the other parameters. Draft data collected with this system was internally stored and then downloaded to a laptop computer. The sampling rate for the draft system was $25 \mathrm{~Hz}$ while the other data was collected at $1 \mathrm{~Hz}$. A link between the two systems existed in the form of a switch that emitted a digital signal to the file depending on the state of the equipment. When tillage was in progress, the switch was turned to the "on" position outputting a " 1 " to the text file collected with the other system. When tillage was not in progress the switch was in the "off" position outputting a " 0 " to the text file. The data from both systems was combined post-collection. Only the data that was collected while tilling was analyzed.

\section{Multiple Depth Tillage Experiment}

A 0.18 acre of Marvyn loamy sand soil at the E.V. Smith Research and Extension Center in Shorter, AL was chosen for this experiment. The field was divided into 16 plots measuring $10 \mathrm{ft}$. wide by $50 \mathrm{ft}$. long. There were 4 treatments applied to four randomly selected plots for each treatment. Treatments 1 and 2 were performed at a shallow depth of 9 in. and treatments 3 and 4 at a 14 in. tillage depth. A mechanical front wheel drive (MFWD) John Deere 8300 agricultural tractor was implemented with a KMC 4 shank in row subsoiler, shown in Figure 1.

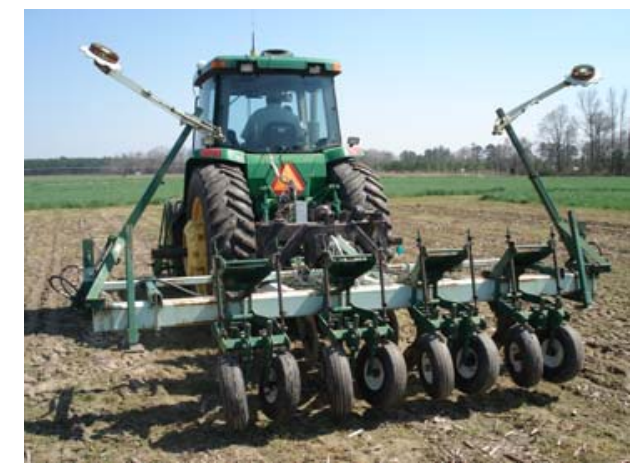

Figure 1. John Deere 8300 with the KMC Subsoiler Attached.

A Trimble real time kinematic (RTK) Auto-Pilot system aided the operator in correctly aligning the tractor within each plot. Data collection was started when the tillage implement was lowered. A travel speed of $3.0 \mathrm{mph}$ was maintained for all tests. Fuel consumption, wheel 
speed, ground speed, and GPS positions were collected at $1 \mathrm{~Hz}$ with the draft data collected at a rate of $25 \mathrm{~Hz}$. All tillage for this experiment was performed with the MFWD engaged. Soil samples of 0 in. to 6 in. and 6 in. to 12 in. were collected for each plot to determine soil moisture content.

Prior to analysis, the draft data was averaged into one second intervals and then merged with the tractor performance data based on time. Once merged, data was trimmed to remove data at the start and end of data collection so only data from within each plot was used. Analysis was performed using Statistical Analysis System (SAS ${ }^{\mathrm{TM}}$ ) statistical package. Draft and fuel consumption data was averaged per plot. The least significant difference (LSD) test was performed using a significance level of 0.05 to test for significant differences between and within treatments.

\section{Tillage Longevity Experiment}

A test of implement selection and time rotation was done on a 1.9 acre field of Marvyn loamy sand soil at the E.V. Smith Research and Extension Center. Annual, biennial, and triennial tillage rotation treatments existed. Treatments were composed of 3 different implements under 3 different time rotation practices for a total of 9 different configurations. Each of the 9 treatments was replicated four times. The replications were randomly assigned to plots which measured $13.3 \mathrm{ft}$. wide by $85 \mathrm{ft}$. long. The same MFWD 8300 John Deere agricultural tractor implemented with the same data acquisition system was used as described above. Implements included a KMC straight shank subsoiler, a Bigham Brothers Paratill ${ }^{\circledR}$, and a Bigham Brothers TerraTill $^{\circledR}$. Figure 2 shows the latter two implements which are a bent shank design. The bent shank subsoilers are designed to "bend" the subsoil in order to alleviate the hardpan (Bigham Brothers, 2007). The difference between the Paratill ${ }^{\circledR}$ and TerraTill ${ }^{\circledR}$ is the amount of outward bend. The TerraTill ${ }^{\circledR}$ extends 5 in. perpendicularly to the shank compared to 8.5 in. seen with the Paratill ${ }^{\circledR}$.
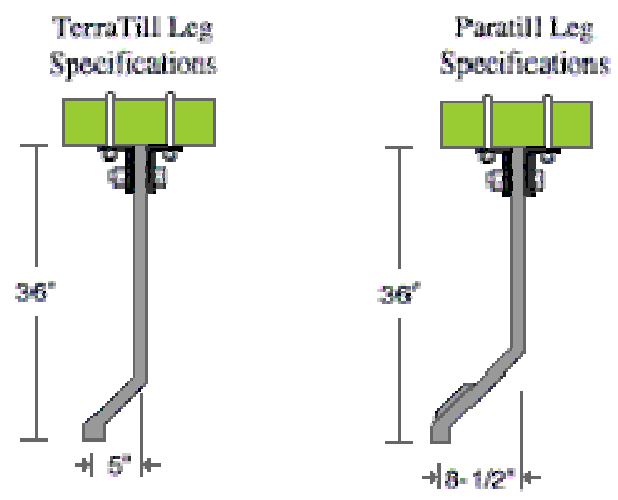

Figure 2. Comparison of the Bigham Brothers TerraTill ${ }^{\circledR}$ leg (left) and Paratill ${ }^{\circledR}$ leg (right). Courtesy: Bigham Brothers.

The same procedure for data collection and analysis was used as described above. However, the MFWD was disengaged and axle torque was also a variable collected for this experiment. A tillage depth of 13 in. from the ground surface to the shank bottom was preset prior to beginning the experiment for all implements. Again, soil samples were collected on a per plot basis to determine soil moisture content. 


\section{Results and Discussion}

\section{Multiple Depth Tillage Experiment}

The soil moisture content as percent dry basis was between $10 \%$ and $11 \%$ for all plots. Table 1 presents averages and standard deviations (S.D.) for draft and fuel consumption. Results indicate an increase in draft loads and fuel consumption for the 14 in. tillage depth. According to the SAS ${ }^{\mathrm{TM}}$ results, statistical differences exist between the 9 in. depth and the $14 \mathrm{in}$. depth for draft. Just by visual examination, there is an increase in draft forces at the deeper depth compared to the 9 in. depth. Over just a 5 in. increase of depth, draft forces increased by $120 \%$. In reference to site-specific tillage, the data puts into perspective the potential to reduce energy consumption by tilling at no depth deeper than required to disrupt the soil compaction layer. Decreased draft loads imply less stress on expensive equipment leading to extended equipment life.

Table 1. Summary of Draft and Fuel Consumption Results for the Multiple Depth Tillage Experiment.

\begin{tabular}{ccccccc}
\hline \multirow{2}{*}{$\begin{array}{c}\text { Depth } \\
\text { (in.) }\end{array}$} & Treatment & \multicolumn{2}{c}{ Draft (lbs) } & & \multicolumn{2}{c}{ Fuel (gal/hr) } \\
\cline { 7 - 7 } \cline { 6 - 7 } & & Mean* $^{*}$ & S.D. & & Mean* & S.D. \\
\hline 9 & 1 & $2,461^{\mathrm{b}}$ & 80 & & $4.5^{\mathrm{b}}$ & 0.10 \\
9 & 2 & $2,176^{\mathrm{b}}$ & 75 & & $4.3^{\mathrm{b}}$ & 0.14 \\
14 & 3 & $5,129^{\mathrm{a}}$ & 357 & & $5.4^{\mathrm{a}}$ & 0.13 \\
14 & 4 & $5,039^{\mathrm{a}}$ & 172 & & $5.2^{\mathrm{a}}$ & 0.15 \\
\hline
\end{tabular}

Note: *Means with similar letters in columns have no statistical differences $(\alpha=0.05)$.

In terms fuel consumption, statistically significant differences $(p<0.05)$ existed between the 9 in. and 14 in. tillage depth. Referring to Table 1 above, fuel consumption increased as the tillage depth increased. However, the difference in fuel consumption was not as great as seen with draft forces; nevertheless a $17 \%$ decrease in fuel consumption was achieved at the shallower depth. In terms of site-specific tillage, subsoiling performed at depths shallower than the deepest depth required to disrupt the compaction layer has the potential to provide significant reductions in draft load leading to increased fuel economy especially over large fields.

On a volumetric fuel consumption basis, the $9 \mathrm{in}$. depth averaged $4.4 \mathrm{gal} / \mathrm{hr}$ which is approximately $1 \mathrm{gal} / \mathrm{ac}$ of fuel usage. The $14 \mathrm{in}$. tillage treatment averaged $5.3 \mathrm{gal} / \mathrm{hr}$ equaling approximately $1.2 \mathrm{gal} / \mathrm{ac}$ of fuel usage. These calculations only account for tillage itself and do not account turning at headlands and any potential idle periods. This type of data can be used to compute fuel consumption on a field specific basis rather than as a total farm average, supplying producers more specific information on fuel consumption and fuel costs.

\section{Tillage Longevity Experiment}

Table 2 presents a statistical summary of fuel consumption, draft force, and axle torque for the 
three implements. The rotation column in the table refers to the amount of time between tillage events, i.e. annual, biennial, and triennial. Soil moisture content (MC) ranged between $9.3 \%$ and $10.5 \%$ for all treatment plots.

Table 2. Summary of Results for the Tillage Longevity Experiment.

\begin{tabular}{|c|c|c|c|c|c|c|c|c|}
\hline \multirow{2}{*}{ Implement } & \multirow{2}{*}{ TRT } & \multirow{2}{*}{$\begin{array}{l}\text { Rotation } \\
\text { (yrs.) }\end{array}$} & \multicolumn{2}{|c|}{$\begin{array}{c}\text { Fuel Usage } \\
\text { (gal/hr) }\end{array}$} & \multicolumn{2}{|c|}{$\begin{array}{l}\text { Draft } \\
\text { (lbs) }\end{array}$} & \multicolumn{2}{|c|}{$\begin{array}{l}\text { Torque } \\
\text { (ft-lbs) }\end{array}$} \\
\hline & & & Mean* & S.D. & Mean* & S.D. & Mean* & S.D. \\
\hline \multirow[t]{3}{*}{ KMC } & 1 & 1 & $4.4^{c}$ & 0.2 & $2,882^{d}$ & 265 & $6,023^{d}$ & 1,448 \\
\hline & 2 & 2 & $4.5^{\mathrm{c}}$ & 0.2 & $3,075^{\mathrm{cd}}$ & 190 & $6,405^{\mathrm{cd}}$ & 538 \\
\hline & 3 & 3 & $4.7^{\mathrm{bc}}$ & 0.2 & $3,685^{c}$ & 324 & $7,325^{\mathrm{bc}}$ & 581 \\
\hline \multirow[t]{3}{*}{ Paratill@ } & 4 & 1 & $4.9^{b}$ & 0.2 & $4,854^{b}$ & 530 & $7,626^{\mathrm{bc}}$ & 1,573 \\
\hline & 5 & 2 & $4.9^{b}$ & 0.2 & $4,655^{\mathrm{b}}$ & 531 & $8,142^{b}$ & 999 \\
\hline & 6 & 3 & $5.3^{\mathrm{a}}$ & 0.3 & $5,953^{a}$ & 793 & $9,516^{\mathrm{a}}$ & 620 \\
\hline \multirow[t]{3}{*}{ TerraTill囚 } & 7 & 1 & $5.4^{\mathrm{a}}$ & 0.0 & $5,683^{a}$ & 148 & $9,713^{a}$ & 507 \\
\hline & 8 & 2 & $5.4^{\mathrm{a}}$ & 0.1 & $5,625^{\mathrm{a}}$ & 117 & $9,675^{\mathrm{a}}$ & 597 \\
\hline & 9 & 3 & $5.5^{\mathrm{a}}$ & 0.1 & $5,975^{\mathrm{a}}$ & 404 & $10,066^{a}$ & 229 \\
\hline
\end{tabular}

Table 2 illustrates that the KMC subsoiler exhibited some of the lower numbers amongst the implements for fuel consumption, draft, and axle torque. The TerraTill ${ }^{\circledR}$ seemed to have some of the larger parameter values with the Paratill ${ }^{\circledR}$ in the middle. No statistical differences were found within the entire TerraTill ${ }^{\circledR}$ group for all three parameters. Nevertheless, there seems to be an increase in draft and torque for the TerraTill ${ }^{\circledR}$ from the annual and biennial frequency to the triennial rotation along with a slight increase in fuel consumption. The triennial Paratill seems to be similar to all the TerraTill ${ }^{\circledR}$ frequencies for all parameters. Results indicate an $8 \%$, $25 \%$, and $21 \%$ increase in fuel consumption, draft forces, and torque, respectively, with the triennial rotation compared to the annual and biennial Paratill ${ }^{\circledR}$ rotation. The trend continues with the triennial $\mathrm{KMC}$ having increases of $6 \%, 24 \%$, and $18 \%$ in fuel consumption, draft forces, and torque, respectively, compared to the annual and biennial KMC rotations. However, the data suggests that an increase in energy requirements occurs for the triennial time rotation for all implements. This trend points toward the possibility of an event that happens between the annual and biennial rotations, and the triennial time rotations. Reasons for this trend are unknown at this time. Overall, the TerraTill ${ }^{\circledR}$ had $20 \%, 79 \%$, and $49 \%$ higher fuel consumption, draft, and axle torque values, respectively, than the KMC in-row subsoiler. The Paratill ${ }^{\circledR}$ had $7 \%, 10 \%$, and $14 \%$ less fuel consumption, draft, and axle torque values, respectively, compared to the TerraTill ${ }^{\circledR}$. In the future, more detailed tests tailored to site-specific tillage will be conducted. Variables such as travel speed and depth will be investigated with different tillage implements, providing a basis for more decisive results on management for implement operations of site-specific tillage.

Future research will consist of expanding on this initial research for quantifying the energy and costs associated with site-specific tillage compared to uniform depth tillage. Additional tractor 
performance data beyond what was reported in this paper will be collected. Different implements operated at varying ground speed and depths are planned. Limitations in terms of depth and speed will help better understand proper implementation of site-specific tillage.

\section{Conclusions}

The two experiments reported within this paper were the first opportunity to test the developed data acquisition system. The system proved to be accurate and reliable for collecting real-time machine performance parameters. Data collected using this system and a 3-D draft load sensor system were used to collect data on two tillage experiments. Trends from the two tillage depth experiments showed an increase in fuel consumption (20\%) and draft force $(120 \%)$ when comparing the $9 \mathrm{in}$. and the $14 \mathrm{in}$. tillage depths. The $9 \mathrm{in}$. depth averaged $4.4 \mathrm{gal} / \mathrm{hr}$ of fuel consumption equating to approximately $1 \mathrm{gal} / \mathrm{ac}$ of fuel usage compared to $1.2 \mathrm{gal} / \mathrm{ac}$ of fuel usage at the $14 \mathrm{in}$. tillage depth which averaged $5.3 \mathrm{gal} / \mathrm{hr}$. These results were expected and support previous research on site-specific tillage. The multiple implement tillage longevity experiment indicated no significant differences in fuel consumption, draft load, and axle torque for the TerraTill ${ }^{\circledR}$ over all the 3 rotational years. However, a general trend of rising fuel consumption, draft loads, and axle torque values was observed as the time since tillage increased. In general, the KMC in-row subsoiler realized $44 \%, 17 \%$, and $33 \%$ lower draft, fuel consumption, and axle torque values, respectively, when compared to the TerraTill ${ }^{\circledR}$. The ParaTill ${ }^{\circledR}$ experienced $10 \%, 7 \%$, and $14 \%$ less draft, fuel consumption, and axle torque values, respectively, compared to the TerraTill ${ }^{\circledR}$. These results indicate that the choice of implement can influence energy requirements and site-specific tillage can provide energy savings and thereby cost savings to producers.

\section{References}

Abbaspour-Gilandeh, Y., A. Khalilian, R. Alimardani, A Keyhani, and S.H. Sadati. 2005. Energy savings with variable-depth tillage. In Proc. 2005 Southern Conservation Tillage Systems Conference.

Bigham Brothers. 2007. Subsoilers:TerraTill@. Lubbock, Tx. htpp://www.bighambrothers.com. Accessed May 6, 2007.

Fulton, J.P., L.G. Wells, S.A. Shearer, and R.I. Barnhisel. 1996. Spatial variation of soil physical properties: a precursor to precision tillage. ASAE Paper No. 961002. St. Joseph, Mich.: ASAE.

Grisso, R. and Pitman, R. 2001. Gear up and throttle down - Saving fuel. Virginia Cooperative Extension Paper No. 442-450.

Jenane C., L.L. Bashford, and G. Monroe. 1996. Reduction of fuel consumption through improved tractive performance. J. Agric. Engng. Res. 64: 131-138.

Raper, R.L., Reeves, D.W., Shaw, J.N., van Santen, E., Mask, P.L. 2005a. Site-specific subsoiling benefits for cotton production. ASAE Paper No. 051025. St. Joseph, Mich.: ASABE.

Raper, R.L., Schwab, E.B., Balkcom, K.S., Burmester, C.H., Reeves, D.W. 2005b. Effect of 
annual, biennial, and triennial in-row subsoiling on soil compaction and cotton yield in southeastern U.S. silt loam soils. Applied Engineering in Agriculture. 21(3): 337-343.

Raper, R.L. 2002. Force requirements and soil disruption of straight and bentleg subsoilers for conservation tillage systems. In Proc. 2002 ASAE International Meeting. ASAE Paper No. 021139. St. Joseph, Mich.: ASAE.

Raper, R.L., D.W. Reeves, J.N. Shaw, E. van Santen, and P.L. Mask. 2004. Site-specific subsoiling: Benefits for coastal plain soils. In Proc. 26th Southern Conservation Tillage Conference, Raleigh N.C.

SAS. 2007. SAS for Windows. Ver. 9.1. Cary, N.C.: SAS Institute, Inc.

Schrock, M.D., Hatteson, D.K., and Thompson, J.G. 1982. A gear selection aid for agricultural tractors. ASAE Paper No. 82-5515. St. Joseph, Mich.: ASAE.

Yule, I.J., Kohnen, G., and Nowak, M. 1999. A tractor performance monitor with DGPS capability. Computers and Electronics in Agriculture. 23(1999): 155-174. 